\title{
Description and some biological aspects of Acarophenax dominicai n. sp. (Acari: Heterostigmata: Acarophenacidae), an egg parasite of lesser grain borer, Rhyzopertha dominica (F.) (Coleoptera: Bostrichidae)
}

\author{
Sayed A. Eraky*; Samy H. Mohamed*; Youssef M. Omar*; Ahmad I. Farghal*; \\ Azza A. Mohamed ${ }^{* *}$ and Wafaa A. Haridy ${ }^{*}$ \\ *Plant Protection Department, Faculty of Agriculture, Assiut University, Assiut 71526 Egypt, seraky53@yahoo.com. \\ ${ }^{* *}$ Plant Protec. Res. Institute, Agric. Res. Cent. Dokki, Giza, Egypt, azza.abdelgawad@yahoo.com.
}

\begin{abstract}
A new species of mite, Acarophenax dominicai was described and illustrated based on male and phoretic female. The new species was reported parasitizing of lesser grain borer, Rhyzopertha dominica (F.) eggs infested wheat grains. Adult females of this species most closely resemble those of Acarophenax lacunatus Cross and Krantz (1964). The new species is separable from A. lacunatus by its smaller size, ornamentations on dorsum and venter, the shape of tergite margins; aggenital plate; gnathosoma, as well as the chaetotaxy of legs I-IV. Holotype female and five paratype females; holotype male and four paratype males, were deposited in the Acari collection of Plant Protection Department, Faculty of Agriculture, Assiut University, Egypt. Some biological aspects are provided. Female mite produces one close d eggs capsule and remains alive until the capsule comes out. Female mites settle on the dorsum of host female during the pre-oviposition period, then leave the host in the period of oviposition and feed on egg's contents. Male mites are ephemeral and may not emerge from the gravid-female. Mite sex ratios are highly skewed, with an average of $19.7 \pm 0.3$ : $0.77 \pm 0.23$ females to males (mite progeny/eggs capsule/gravid-female). When females reach adulthood, mating take place either within the gravid-female (if present) or with a male which has previously emerged from another eggs capsule. Male mites are not parasitic and had poor locomotion abilities.
\end{abstract}

Key words: Acarophenax dominicai; Acarophenacidae; Rhyzopertha dominica; biological aspects; Mites.

\section{INTRODUCTION}

The family Acarophenacidae (Acari: Heterostigmata) currently consists of 7 genera (one fossil and six extant), and about 39 described species. The fossil genus is: Protophenax Magowski, 1994 and the extant genera include: Acarophenax Newstead and Duvall, 1918; Adactylidium Cross, 1965; Aegyptophenax Rady, 1992; Aethiophenax Mahunka, 1981; Paracanophenax Cross, 1965 and Paradactylidium Mahunka, 1975 (Magowski, 1994; Arjomandi et al., 2017; Walter and Seeman, 2017; Khaustov and Abramov, 2018; Xu et al., 2018 and Khaustov and Abramov, 2019). Members of the family Acarophenacidae are known as egg parasitoids of various insects, including beetles pertaining to the families: Bostrichidae, Cerambycidae, Tenebrionidae, Nitidulidae, Dermestidae, Curculionidae, Mycetophagidae, Cucujidae and Erotylidae, as well as thrips (Thysanoptera) (Goldarazena et al., 2001; Rahiminejad and Hajiqanbar. 2015; Katlav et al., 2015; Arjomandi et al., 2017; Walter and Seemen, 2017; Khaustov and Abramov, 2018; Xu et al., 2018 and Khaustov and Abramov, 2019). The Acarophenax Newstead and Duvall, 1918 is the important acarophenacid genus, which includes members may be useful as natural control agents, because they parasitizing of some graminivorous beetle eggs. So far, there are 12 species in the genus Acarophenax (i.e., A. traegadhi krczal, 1959; A. lacunatus Cross and Krantz, 1964; A. assanovi Livshitz and Mitrofanov, 1974; A. nidicolus
Cross and Krantz, 1964; A. lukoschusi Mahunka and Fain, 1989; A. makros Gao and Zou, 1994; A. mahunkai Steinkraus and Cross, 1993; A. sphindi Rahiminejad and Hajiqanbar, 2015; A. tribolii Newstead and Duvall, 1918; A. meropsi Rakha and Kandeel, 1983; A. rackae Mahunka and Zaki, 1990 and A. dominicai n. sp.).

\section{Systematics}

Family Acarophenacidae Cross, 1965

Genus Acarophenax Newstead and Duvall, 1918

Acarophenax dominicai n. sp.

Diagnosis: Adult females of this species most closely resemble those of Acarophenax lacunatus Cross and Krantz (1964). The new species separable from $A$. lacunatus by its small size, ornamentations on dorsum and venter, the shape of tergite margins; aggenital plate; gnathosoma, as well as the chaetotaxy of legs I-IV, (male of A. lacunatus is unknown).

Description of non-gravid female (Figs. 1-20). Holotype female and five paratype females were measured. Body elongated-ovoid.

Gnathosoma (Figs. 1-4). Elongated, fused with idiosoma. Palps fused with gnathosomal capsule, gnathosoma with 3 pairs of palpal pits discernible, located apically, medially and basally, each bearing a small needle-like setae. Chelicera stylets strong and curved. Pharynx enlarged and almost elliptical. Gnathosoma dorsally with well-visible elongated 


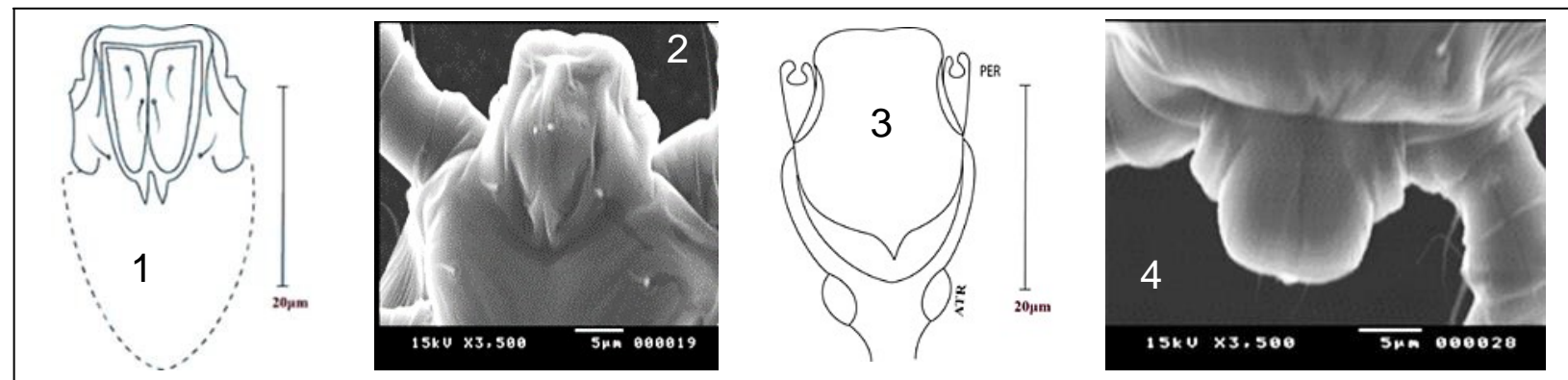

Figs. (1-4). A. dominicai female. Gnathosoma,. 1\&2 (ventral aspect); 3\&4 (dorsal aspect).

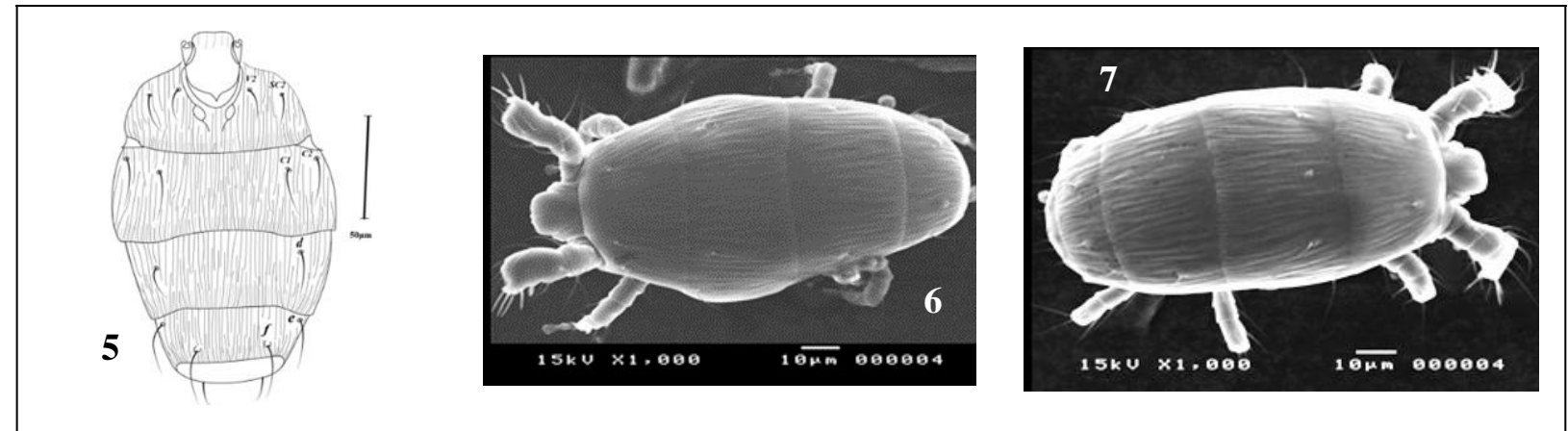

Figs. (5-7). A. dominicai female. Dorsal side.

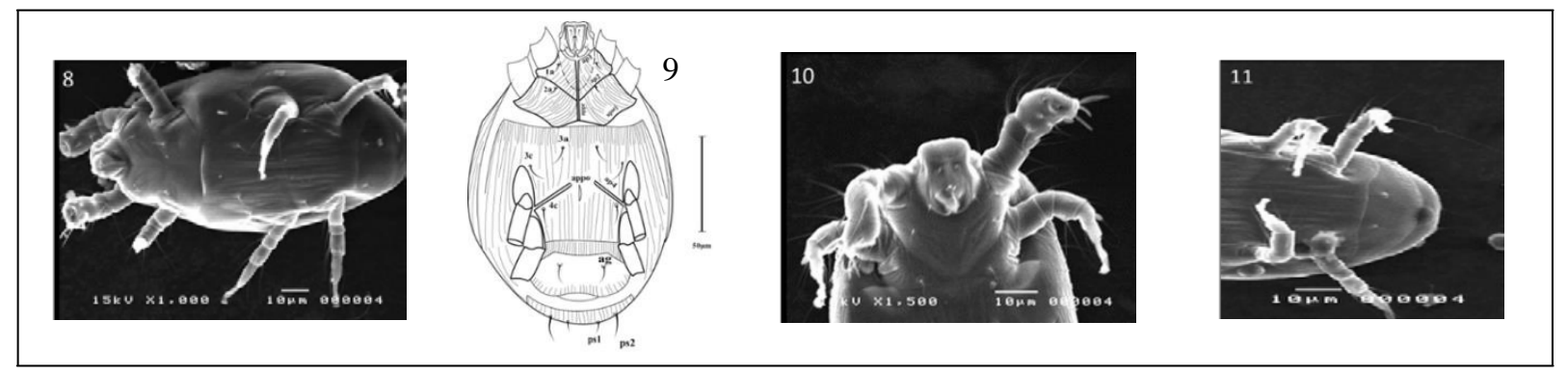

Figs. (8-11). A. dominicai female. $8 \& 9$ ventral side; 10 anterior ventral plate; 11 posterior ventral plate.

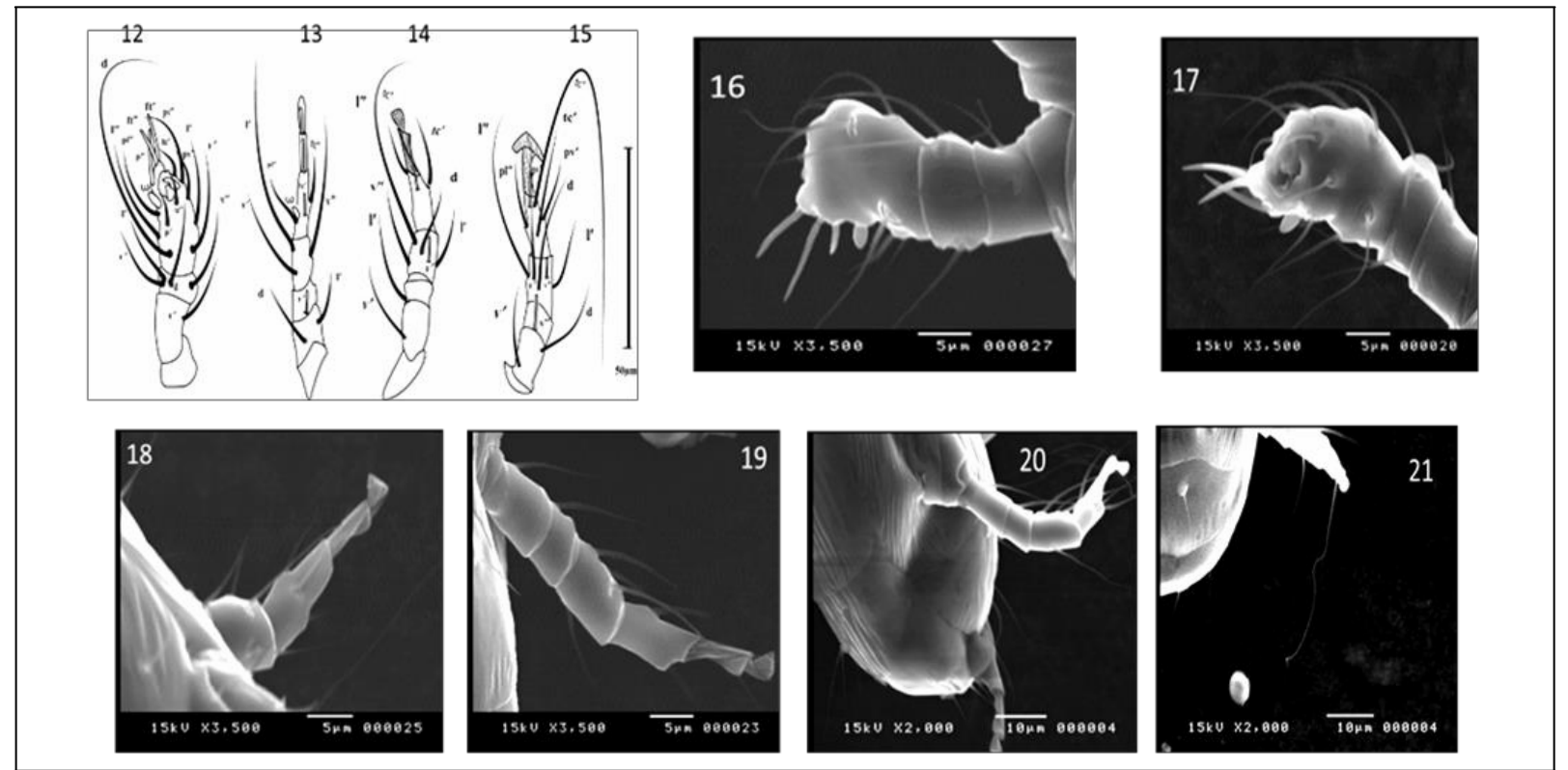

Figs.12-21, A. dominicai female. 12,16 \&17 leg I; 13\&18 leg II; 14 \&19 leg III; 15,20 \&21 leg IV. 
tracheal trunks, located on anterior margin of prodorsal shield, each ends with an oval-like atrium. Dorsal gnathosomal setae reduced. Gnathosoma: 30 (29-31) long, 17 (15-19) wide.

Idiosomal dorsum (Figs. 5-7). Body approximately ovate, 110 (100-120) long, 92 (90-94) wide. Prodorsal shield trapezoidal, with two pairs of setae $\left(\mathrm{v}_{2}\right.$ and $\left.\mathrm{sc}_{2}\right)$. Stigmata on prodorsal projection associated with tracheal system and atria. Tergite $\mathrm{C}$ with two pairs of setae (c1 and c2); tergite D with one pair of setae(d); tergite EF with two pairs of setae (e and $\mathrm{f}$ ); tergite $\mathrm{H}$ without setae; all dorsal setae simple ,slightly long and thick with blunt-ended, as well as, setae e and f, approximately subequal in length.

Prodorsal shield and all dorsal tergites ornamented with irregular, longitudinally striations, heavy above posterior margins of tergites, except tergite $\mathrm{H}$, smooth, without any sculpture. Length of setae on dorsum, venter and legs (Holotype female measured), $\mathrm{v}_{2} 7, \mathrm{sc}_{2} 10, \mathrm{c}_{1} 12, \mathrm{c}_{2} 20$, d 17, e and f 24; distance between setae: $\mathrm{V}_{2}-\mathrm{V}_{2}(18), \mathrm{sc}_{2}-\mathrm{SC}_{2}(40), \mathrm{V}_{2}-\mathrm{Sc}_{2}(11), \mathrm{c}_{1}-$ $c_{1}$ (36), $c_{2}-c_{2}$ (56), $c_{1}-c_{2}$ (10), d-d (40), e-e (34), f-f (16), e-f (11).

Idiosomal venter (Figs. 8-11). Ventral plates ornamented with irregular, longitudinally striations, heavy on anterior portion of posterior ventral plate; above aggenital plate and posterior portion of plate PS and aggenital one. All ventral setae smooth and simple. On anterior ventral plate, apodemes 1(ap1), apodemes 2 (ap2) and sejugal apodeme (apsej), well developed, jointed with prosternal apodeme (appr), ap1 fused with appr to form a Y-shaped structure with anterior branches surrounding the base of gnathosoma. Coxisternal plates I and II, with one pair of setae each (1a 8, 2a 11). On posterior ventral plate, apodemes 3 (ap3) and apodemes 5 (ap5) missing, apodemes 4 (ap4) well-developed, furcate laterally and incomplete medially; posterior apodeme (appo), reduced, short, visible only between ap 4; posterior ventral plate with three pairs of setae. Coxal field III with two pairs of setae (3a and 3c), equal in length (10), coxal field IV with one pair of setae 4c (10); aggenital plate with a pair of setae ag (10), plate PS with two pairs of setae, ps1 (6) and ps2 (12).

Legs (Figs. 12-21). Length of legs (Holotype female measured): leg I (40), leg II (45), leg III (43), leg IV (44). Leg I, much thicker than other legs, tibia and tarsus on leg1 fused in one segment (TiTa); tibiotarsus on leg1 with solenidion $\omega$ (4), fingershaped; leg1 setation: Fe1, Ge 4, TiTa $13(\omega)$. Setae tc' (6), tc” (5), ft' and ft” (9), p' (5). P” (9) eupathidium-like; setae d (30) on tibiotarsus, very long, whip-like; other leg setae (except eupathidia), slightly long and smooth, their lengths ranged between 6-18 $\mu \mathrm{m}$. Leg II, leg setation: Fe 2, Ge1, Ti 3 , Ta $3(\omega)$. Tarsus with soleidion $\omega(3)$ prominent and finger-shaped; setae v' (3) on genu and tc' (4) on tarsus, eupathdium-like; setae d (16) and l' (10) on femur; v' (12), v" (13) and l' (19) on tibia, long and whip-shaped; setae tc" and pl" on tarsus sub equal in length (9). Leg III. Leg setation: Fe 1, Ge 1, Ti 5, Ta 3 ; setae v' on femur, l' on genu, l', d, v" on tibia subequal in length (9-11), l" very long (31) and whiplike; tarsus with tc" (7) and tc' (8); setae v' on tibia and $\mathrm{pl}$ ” on tarsus eupathidium -like. Leg IV, leg setation: Fe 2, Ge 1, Ti 5, Ta 5; setae v" on Ge and tibia, pv" on tarsus eupathidium-like, longer on tarsus; seta tc" (60) on tarsus very long and whip-like; seta l" (22) on tibia, longer than other tibial and genual setae (ranged between 7-16 $\mu \mathrm{m}$ ). All setae on leg IV smooth, except eupathidial ones.

Description of male (Figs. 22-29). Body approximately oval. Gnathosoma (Fig. 22), reduced, with only a pair of slightly long, stout and bluntended solenidia, directed forward ventrally, in addition to a pair of simple, thin setae on gnathosomal base. In alive male, the anterior part of gnathosoma can be extended anteriorly. This demonstrated that gnathosoma not completely fused ventrally. Chelicera and palpi reduced, as well as dorsal gnathosomal setae. Gnathosoma, approximately triangular in its shape, 14 (13-15) long, 11 (10-12) wide.

Dorsum (Figs. 23-24). (Holotype male and four paratype males measured). Idiosoma oval, 88 (86-90) long, 82(80-84) wide; cuticle smooth, without any sculpture. Body divided into two segments (proterosoma and hysterosoma). Each with two pairs of setae; the hysterosomal setae slightly longer than proterosomal ones. All dorsal setae simple and smooth. Length of dorsal setae: $\mathrm{sc}_{1} 12(10-14), \mathrm{sc}_{2} 9$ (8 - 10), c 8 (8 - 8) and d 8 (6-10). Gnathosoma and genital opening clearly appeared on ventral aspect.

Venter (Figs. 25-26). All apodemes, well- developed. On anterior ventral plate, ap1, ap2 and apsej welldefined, jointed with prosternal apodeme (appr), ap1 fused anteriorly with appr to form a Y-shaped structure with anterior branches surrounding the base of gnathosoma. Coxisternal plates I and $1 \mathrm{~V}$, with one pair of setae each (1a and 4a); coxisternal plates II and III, with two pairs of setae each (2a, 2b, and 3a, 3c). Setae ag absent; plate PS with two long and thick setae (ps1 and ps2), ps2 longer than ps1. Apodeme 5 (ap5) reduced. Opisthosomal capsule, conical-like structure. Length of setae: 1a 5 (4-6), 2a 8 (6-10), 3a 7 (5-9), 2b 7 (6-8), 3c 7 (6-8), 4a 7 (6-8), ps1 11 (10$12)$ and ps2 13 (12-14). 


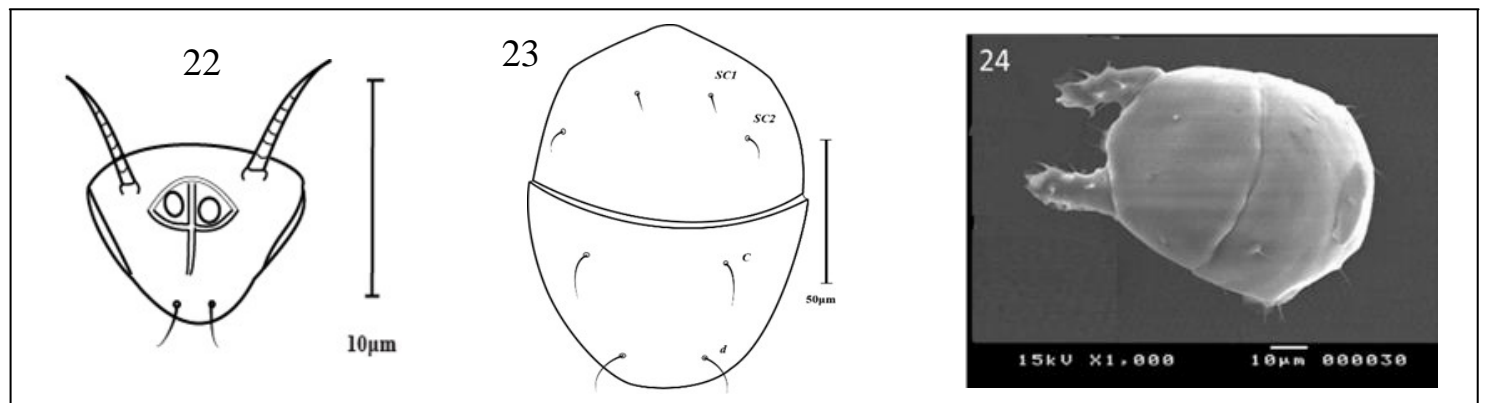

Figs. (22-24): A. dominicai male. 22 gnathosoma; 23\&24 dorsal side.

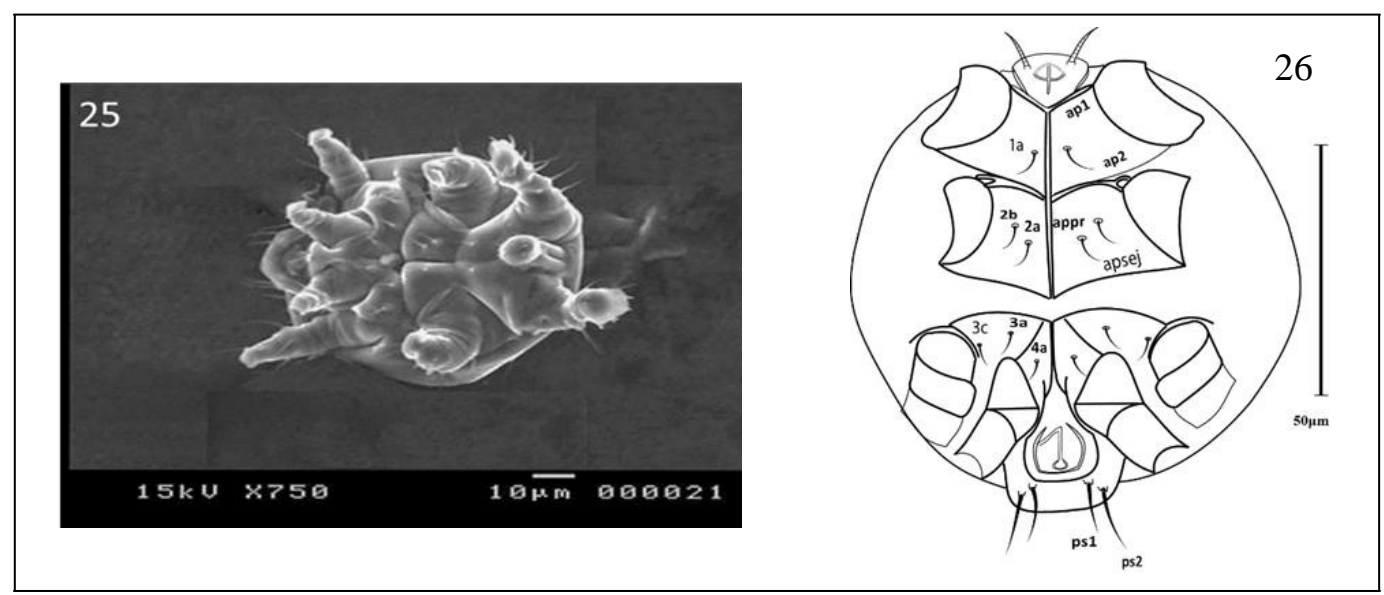

Figs.(25-26): A. dominicai male. Ventral side.

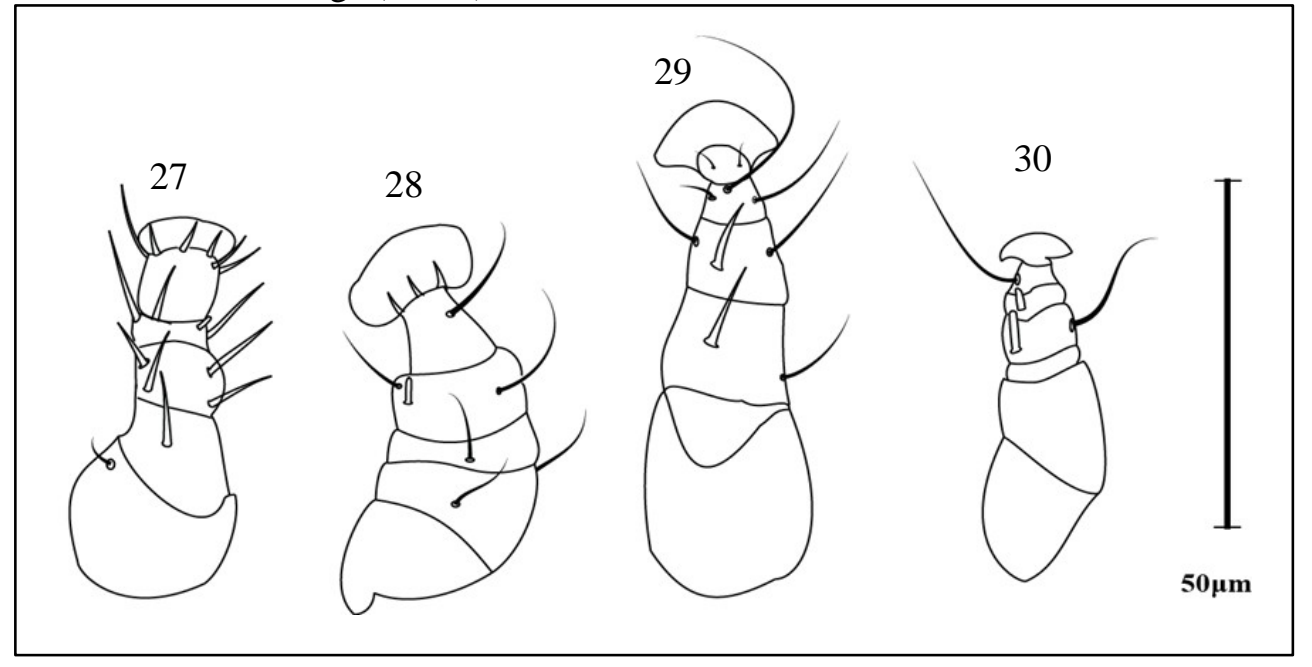

Figs. (27-30): A. dominicai male. 27 leg I; 28 leg II; 29 leg III; 30; leg IV.
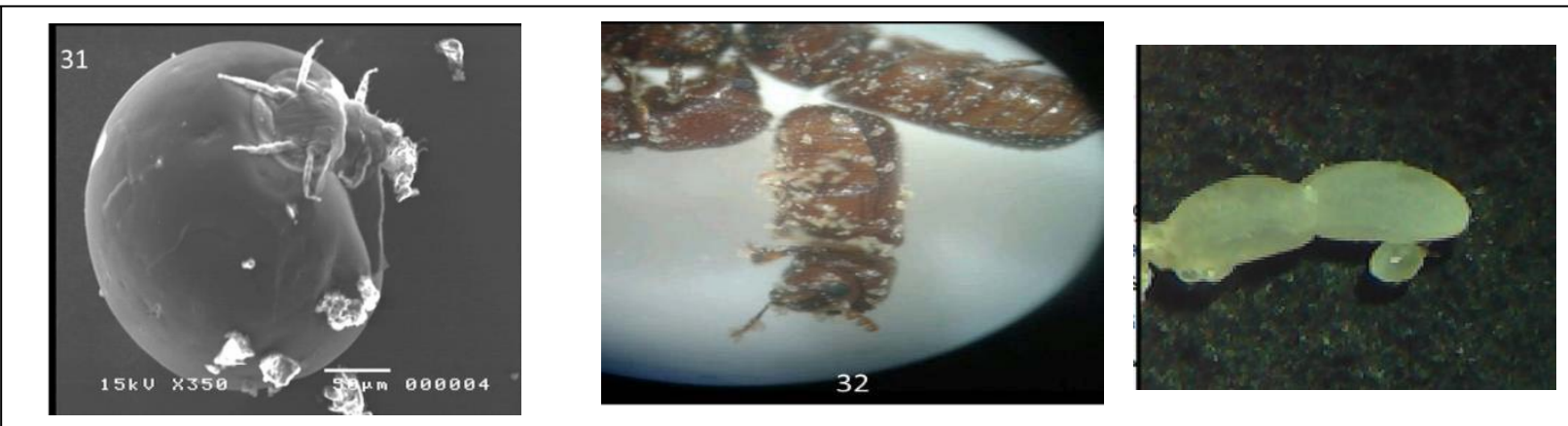

Figs. (31-33). A. dominicai female. 31 gravid-female (9 h old); 32 young adult females attached on $R$. dominica female body sites; 33 mite eggs capsule placed close to beetle eggs. 
Legs (Figs.27-30). All legs short, clawless. Leg I 35 (33-37), leg II 33 (32-34), leg III 42 (41-43) and leg IV 29 (27-31). Number of setae on femur, genu, tibia and tarsus, respectively: leg I: $2,3,5$, 7; leg II: 2,1 , 3, 1; leg III: 0, 2, 2, 4; leg IV: 0, 0, 2, 2. Solenidia on legs I and II, hardly visible. Leg I, seta d of femur minute, setiform, l' of the same segment spiniform, very short; 3 setae (d, l', l') of genu, and setae ( $k, 1$ ', d) of tibia slightly long and blunt ended; tarsal setae either spiniform or eupathidial, except (pl', tc"), elongate-flagellate. leg II, setae (l', d) of femur, setae (d) of genu, setae (l', l') of tibia and tc" of tarsus, setiform and elongate. Leg III, with three eupathidial setae on genu, tibia and tarsus, the other leg setae are elongate, setiform, as well as two minute setae on pretarsus. Leg IV, with eupathidial setae on tibia and tarsus, in addition to one flagellate seta each.

Material examined. Holotype female and five paratype females; holotype male and four paratype males, collected from the laboratory culture of Rhyzopertha dominica (F.), at Assuit Governorate, Egypt, June 20, 2019, were deposited in the Acari collection of Plant Protection Department, Faculty of Agriculture, Assiut University, Egypt.

\section{Some biological aspects of $A$. dominicai}

The laboratory stock population of lesser grain borer, $R$. dominica on wheat grains was used to sustain the parasitic mite, A. dominicai. The host females in the period of pre-oviposition with their phoretic newly-emerged female mites (30-70 young adult female mites on host female body) (Fig, 32), were collected and individually placed in Petri dishes (9 cm diameter), when the female hosts started to lay eggs, the parasitic females left the host females in search of eggs for feeding. Newly gravid-females of A. dominicai (1-3 h), were individually placed in small Petri dishes (5 $\mathrm{cm}$ diameter), each dish was provided with 20 host eggs and sufficient amount of hard wheat grains, held at $30 \pm 1^{\circ} \mathrm{C}$ and $65 \pm 5$ R.H. Female mites enlarged rapidly after parasitizing host eggs, approximately $9 \mathrm{~h}$ (Fig. 31), single female mite produced only one closed capsule of eggs (Fig. 33). Respected values are presented as mean \pm SE. The pre-oviposition period of female mite lasted 8-11 h (mean $=9.2 \pm 0.3 \mathrm{~h}$ ); the incubation period of female mite (eggs capsule), lasted 47-51 h (mean $=49.1 \pm$ 0.3 ); the number of mite progeny/eggs capsule ranged of 18-22 female and 0-1 males (mean $=19.7 \pm 0.3$ females and $0.77 \pm 0.23$ males), and the number of host eggs consumed per a single female mite progeny was $11.8 \pm 0.6$ (range $=8-15$ eggs). The parasitic mite, A. dominicai, in common with other members of Acarophenacidae, show the phenomenon of female physogastry (Cross and Krantz, 1964; Steinkraus and Cross ,1993; Faroni et al., 2001; Oliveira et al., 2003).
This is characterized by attachment of the newly emerged females to the host bodies during host preoviposition period, then leave the host in the period of oviposition to feed on the host eggs; the development of progeny occurs within the body of female mite, which subsequently emerge as sexually mature adult. The phoretic attachment of young adult female mites on adult hosts may be the major mechanism for dispersal into new host oviposition sites (Steinkraus and Cross, 1993). However, Newstead and Duvall, 1918; Rack, 1959; Faroni et al., 2000, 2001), found that newly emergent female could begin feeding without first going through a phoretic or conditioning period before feeding. A. dominicai young females leave the host during host oviposition to parasitize the host eggs; after mating either within the gravid-females (Steinkraus and Cross, 1993; Faroni et al., 2000), or outside the gravid-female, where $A$. dominicai males were found attaching to the top of mite eggs capsule, waiting the emergency of females, mating was well observed, this may be due to the lack of male within some eggs capsule.

Adult males of Acarophenax species are ephemeral and may not emerge from physogastric females (Steinkraus and Cross, 1993), but single male of A. lacunatus do emerge from physogastric females (Faroni et al. 2000). On the other hand, female progeny produced per single mother a range of 18-22 young females (mean $=19.7 \pm 0.3, \mathrm{n}=18$ ). Males always produced in scarce numbers, or not be found within the mother, with an average of 0 - 1 male (mean $=0.77 \pm 0.23, n=18$ ). Newstead and Duvall (1918) found that A. tribolii mothers produced 4 - 15 young, but generally only one male; Rack (1959) never found more than one male per $A$. dermestidarum mother, while 3-25 females were produced $($ mean $=14.9 \pm 0.44, n=110)$. Steinkraus and Cross (1993) recorded a range of 7 - 54 female progeny (mean $=27.2 \pm 3.9, \mathrm{n}=15)$ and $1-4$ males (mean $=1.7 \pm 0.2, n=15$ ) produced from $A$. mahunkai physogastric mother. The A. lacunatus females produced about 17 offspring per female when reared on $R$. dominica eggs at $30^{\circ} \mathrm{C}$, the number of progeny decreased at higher and lower temperature, at $41^{\circ} \mathrm{C}$, no production of offspring occurred (Faroni et al., 2000). In the present study, the number of $R$. dominica eggs consumed per progeny of A. dominicai single female, ranged between 10 - 15 (mean= 11.8 $\pm 0.6, \mathrm{n}=18$ ).

Parasitizing efficiency of $A$. dominicai females produced from 3-5 gravid-females on the number of $R$. dominica survived adults for 43 days is presented in Table (1). The oviposition period of lesser grain borer females, lasted an average of $42.95 \pm 3.4$, 
Table (1): Number of $R$. dominica adults survived from 10 females' progeny subjected or not to 3-5 A. dominicai gravid - females' progeny for 43 days

\begin{tabular}{cccccc}
\hline $\begin{array}{c}\text { Oviposition } \\
\text { period (d) }\end{array}$ & $\begin{array}{c}\text { Number } \\
\text { of eggs }\end{array}$ & $\begin{array}{c}\text { Hatchability } \\
(\%)\end{array}$ & $\begin{array}{c}\text { Egg to Adult } \\
\text { (days) }\end{array}$ & \multicolumn{2}{c}{ Survived adults reached when mites } \\
\cline { 5 - 6 } & $322.9 \pm 0.5$ & $47.0 \pm 2$ & $44 \pm 1$ & Present & Absent \\
\hline $42.95 \pm 3.4$ & $32.9 \pm 0.5^{\mathrm{b}}$ & $20.9 \pm 0.99^{\mathrm{a}}$ \\
\hline
\end{tabular}

Means followed by the same letter are not significantly different at .05 probabilities.

*Host females in the period of oviposition, individually placed in Petri dish, with $10 \mathrm{~g}$ hard wheat grains and 3-5 A, dominicai gravid-females, held at $30 \pm 1{ }^{\circ} \mathrm{C}$ and $65 \pm 5$ R.H., $(\mathrm{n}=10)$.

$\mathrm{n}=10$ ). During this period, females laid a mean of $322.9 \pm 0.5$ eggs. Hatchability was $47 \pm 2 \%$ and eggs reached adults after $44 \pm 1$ days on wheat grains, at $30 \pm 1^{\circ} \mathrm{C}$ and $65 \pm 5 \%$ R.H. Parasitism of lesser grain borer female eggs when subjected to 3-5 gravidfemales' progeny, resulted in the reduction of surviving adults after 43 days. Mean number of $R$. dominica adults resulting from eggs capsule laid by a single mother after 43 days was $20.9 \pm 0.99$ (mites absent) compared with $4.5 \pm 0.5$ adults (mites present) (Table 1). This indicated the ability of $A$. dominicai to regulate population of this stored wheat pest. The number of adults decreased significantly by about $75 \%$ as a result of mites present.

Parasitizing by A. dominicai was permanent fatal to lesser grain borer eggs, as was also reported for $A$. mahunkai attacking lesser mealworms by Steinkraus and Cross, (1993). The ability of A. dominicai to reduce the population size of $R$. dominica, the short life cycle of this species, its high fertility at temperature of $30 \pm 1{ }^{\circ} \mathrm{C}$, and no harmful effects on humans. Therefore, authors suggested that, this mite species may be useful as biological control agent of $R$. dominica on stored wheat.

\section{REFERENCES}

Arjomandi, E.; Hajiqanbar, H. and O. Joharchi 2017. Aethiophenax mycetophagi sp. nov. (Acari: Trombidiformes: Acarophenacidae). An egg parasitoid of Mycetophagus quadripustulatus (Coleoptera: Mycetophagidae) from Iran. Systematic and Applied Acarology, 22(4): 541549.

Cross, E.A. and Krantz, G.W. 1964. Two new species of the genus Acarophenax Newstead and Duvall, 1918 (Acarina: Pyemotidae). Acarologia, 6: 287-295.

Cross, E. A. 1965. The generic relationships of the family Pyemotidae (Acarina: Trombidiformes). Univ. Kens. Sci. Bull. 45: 29-275.

Faroni, L.R.; Guedes, R.N.C. and Matioli, A. L. 2000. Potential of Acarophenax lacunatus (Prostigmata: Acarophenacidae) as a biological control agent of Rhyzopertha dominica (Coleoptera: Bostrichidae). J. Stored Pro. Res., 36: $55-63$.
Faroni, L.R.; Guedes, R. N.C. and Matioli, A.L. 2001. Effect of temperature on the development and population growth of Acarophenax lacunatus (Cross and Krantz) (Prostigmata: carophenacidae) on Rhyzopertha dominica (F.) (Coleoptera: Bostrichidae). Biocontrol Sci. Technol., 11: 5-12.

Gao, J.R. and Zou, P. 1994. A new species of Acarophenax (Acari: Acarophenacidae) from China. Entomotaxonomia, 16: 291-294.

Goldarazena, A.; Ochoa, R.; Jordana, R. and O'Connor, B.M. 2001. Revision of the genus Adactylidium Cross (Acari: Heterostigmata: Acarophenacidae), mites associated with thrips Thysanoptera). Proc. Entomol. Soc. Wash., 103: 473-516.

Katlav, A.; Hajiqanbar, H. and Talebi, A.A. 2015. First record of the genus Aethiophenax (Acari: Acarophenacidae) from Asia, redefinition of the genus and description of a new species. J Asia Pacific Entomol. 18(3): 389-395.

Krczal, H. 1959. Systematik and Okologa der pyemotiden. Beitr. Syst. Okol. mitteleur. Acarina, Bd. I: Tyroglyphidae and Tarsonemini, 2: 385625.

Khaustov, A. A. and Abramov, V.V. 2018. A new species of Paracarophenax (Acari: Heterostigmata: Acarophenacidae) associated with Triplax scutellaris (Coleoptera: Erotylidae) from European Russia. Acarologia, 58(2): 332-341.

Khaustov, A. and Abramov, V.V. 2019. First record and redescription of Paracarophenax bambergesis (Acari: Heterostigmata: Acarophenacidae) associated with Amphotis marginata (Coleoptera: Nitidulidae) from European Russia. Acarina, 27(1): 45-51.

Lindquist, E.E. 1986. The world genera of Tarsonemidae (Acari: Heterostigmata): a morphological, phylogenetic, and systematic revision, with a classification of family-group taxa in the Heterostigmata. Mem. Entomol. Soc. Can. 136.

Livishitz, I.Z. and Mitrofanov, V.I. 1974. A new species of parasitic mite (Acariformes: Pyemotidae) from Uzbekistan. Zool. Zh. 53: 288289.

Magowski, W.L. 1994. Discovery of the first 
representative of mite subcohort Heterostigmata (Arachnida: Acari) in the Mesozoic Siberian amber. Acarologia 35: 229-241.

Mahunka, S. 1975. Neue und auf lnsekten lebende Milben aus Australien und Neu-Guinea (Acari: Acaridae, Tarsonemidae). Ann. Hist-nat. Mus. Nat. Hung. 67: 317-325.

Mahunka, S. 1981. Tarsonemiden aus Athiopien (Acari: Tarsonemina). Folia Ent. Hung. 34: 101121.

Mahunka, S. and Fain, A. 1989. New mite species of cohort Tarsonemina (Acari: Acarophenacidae and Pygmephoridae), Parasitol. Hung. 22: 125-136.

Mahunka, S. and Zaki, A.M. 1990. Acarophenax rack sp. n., a new mite species from Egypt (Acari: Tarsonemina: Acarophenacidae). Parasitol. Hung. 23: 121-127.

Newstead, R. and Duvall, H.M. 1918. Bionomic, morphological, and economic report on the acarids of stored grain and flour. R. Soc. Rep. Grain pests (War) Comm. 2: 1-59.

Oliveira, C.R.F.; Faroni, L.R.D’A.; Guedes, R.N.C. and A. Pallini (2003). Parasitism by the mite Acarophenax lacunatus on the beetle pests of stored products. Biocontrol, 48: 503 - 513.
Rack, G. 1959. Acarophenax dermestidarum sp. n. (Acarina: Pyemotidae), ein Eiparasit von Dermestes - Arten. Zeits. F. Parasit., 19: 411-431.

Rady, G.H. 1992. New genus and species of Acarophenacidae (Acari: Tarsonemina) from Egypt. Ann. Agr. Sci. 30: 1129-1135.

Rahiminejad, V. and Hajiqanbar, H. 2015. A new species of the genus Acarophenax (Acari: Heterostigmata: Acarophenacidae) associated with Sphindus sp. (Coleoptera: Sphinidae) from Iran. Persian J. Acarol., 4(3): 277- 286.

Rakha, M.A. and Kandeel, M.M.H. 1983. Acarophenax meropsi n. sp., from the European bee eater, Merops apiaster in Egypt, (Acari: Tarsonemida). Acarologia, 24: 295 - 297.

Steinkraus, D. C. and Cross, E. A. 1993. Description and life history of Acarophenax mahunkai, n. sp. (Acari: Tarsonomina: Acarophenacidae), an egg parasite of the lesser mealworm (Coleoptera: Tenebrionidae). An. Entomol. Soc. Am. 86: 239244.

Walter, D.E. and Seeman, O.D. 2017. A new species of Paracarophenax (Acariformes: Acarophenacidae) with a new means of phoretic attachment. Internat. J Acarol., 43(4): 329 - 335. 